\title{
Donor Motives for Foreign Aid
}

\author{
Subhayu Bandyopadhyay and E. Katarina Vermann
}

The literature on foreign aid has contributed to our understanding of the motives for developed nations to provide aid to developing nations. In this article, the authors primarily focus on donor motivation, but they also touch on the consequences of receiving aid for developing nations. They consider both the developmental and strategic aspects of giving aid. While aid in the 1960s focused more on development, recent aid has increasingly reflected strategic considerations. For example, since the terrorist attacks of September 2001, the objective of reducing terrorism has been of increasing interest among donors giving aid to developing nations. The authors explain the rationale for providing such aid. (JEL F13)

Federal Reserve Bank of St. Louis Review, July/August 2013, 95(4), pp. 327-36.

$\mathbf{T}$ he motives of donor nations for providing foreign aid have evolved over time. $\frac{1}{\text { For }}$ example, prior to World War I, U.S. government-sponsored foreign aid was almost nonexistent. The United States did not financially intervene until World War II, when it began to provide aid abroad, largely through wartime aid and reconstruction efforts. This aid, which focused on "creating markets for the United States by reducing poverty and increasing production in developing countries," also concentrated on "diminishing the threat of communism by helping countries prosper under capitalism" (United States Agency for International Development [USAID, (a)]). These dual goals—humanitarian and strategic-continue to exist in the agency's foreign aid goals to "[develop] the markets of the future... [and] partnerships with countries committed to enabling the private sector investment that is the basis of sustained economic growth to open new markets for American goods" (USAID, (b)). Other nations have similarly altered their donor behavior according to their own histories and evolving environments. For example, a large portion of French aid has been directed to its former colonies, while geopolitical interests have led Japan to give aid to nations broadly supportive of Japanese interests in international forums.

Geopolitical dynamics have evolved over time and, in turn, have affected the decisionmaking processes of donor nations. Figure 1 shows the flow of foreign aid in constant 2011 dollars to

Subhayu Bandyopadhyay is a research officer and economist and E. Katarina Vermann is a senior research associate at the Federal Reserve Bank of St. Louis. The authors thank Alejandro Badel, Maria Canon, and Bill Gavin for their helpful comments.

(c) 2013, The Federal Reserve Bank of St. Louis. The views expressed in this article are those of the author(s) and do not necessarily reflect the views of the Federal Reserve System, the Board of Governors, or the regional Federal Reserve Banks. Articles may be reprinted, reproduced, published, distributed, displayed, and transmitted in their entirety if copyright notice, author name(s), and full citation are included. Abstracts, synopses, and other derivative works may be made only with prior written permission of the Federal Reserve Bank of St. Louis. 


\section{Bandyopadhyay and Vermann}

\section{Figure 1}

\section{Net Official Development Assistance to Regions (1960-2011)}

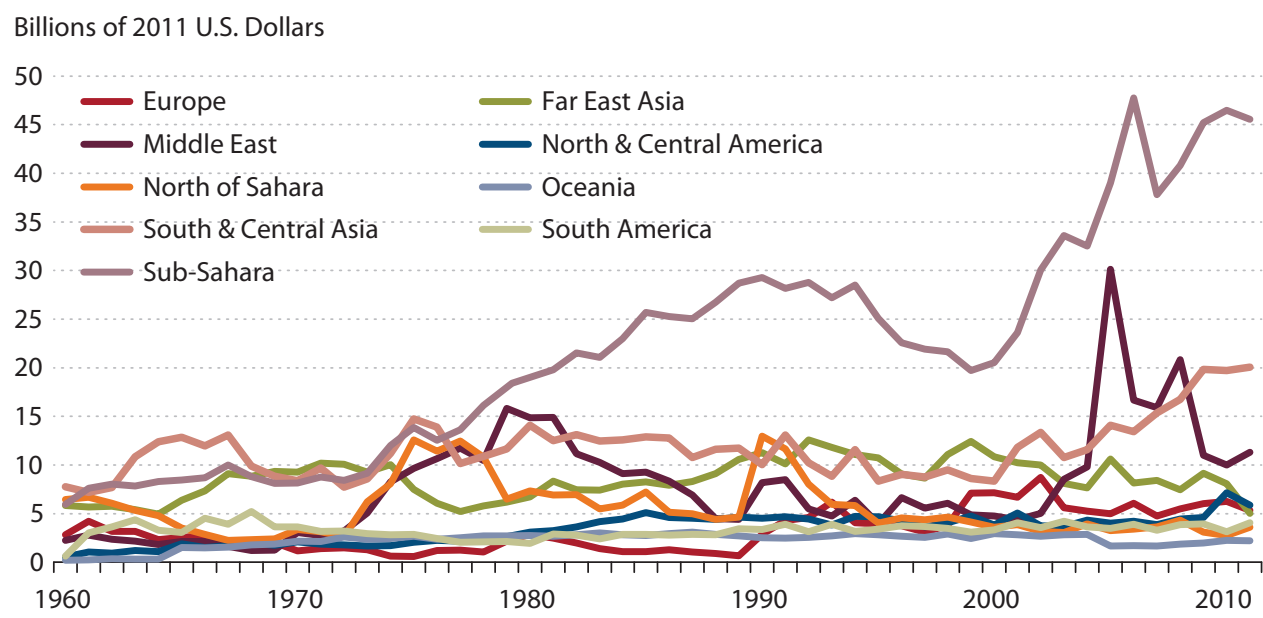

NOTE: The figure shows the real value of net official development assistance allocated to specific geographical regions. Countries in sub-Saharan Africa have consistently received the most official development assistance from all donors, and this amount has grown over time. For the majority of the other regions, however, the amounts received have remained fairly constant. The only exceptions are the Middle East and South and Central Asia, where levels of official development assistance have increased dramatically since 2004.

SOURCE: OECD.

different regions of the developing world from 1960 to 2011. It is clear that the aid flows to subSaharan nations have surged upward from approximately $\$ 6$ billion in 1960 to $\$ 46$ billion in 2011. This pattern is consistent with the objective of providing foreign aid to alleviate poverty and foster development in the poorest of nations, many of which are located in the sub-Saharan region. Also, there was a spike in foreign aid to Middle Eastern nations in 2005, which has been associated with the Iraq War. The growing involvement of the member nations of the Organisation for Economic Co-operation and Development (OECD) in addressing security concerns originating from the Indian subcontinent and surrounding areas is apparent in the pronounced upward trend in aid flows to the South and Central Asia region.

Figure 2 looks specifically at U.S. aid to specific developing nations. In the 1960s, India, then one of the poorest nations in terms of per capita gross domestic product (GDP), received a disproportionate amount of U.S. aid. This development focus shifts somewhat in the 1970s, when Israel and Egypt-U.S. partners in the Middle East peace process-began receiving more U.S. aid. During the Iraq War in the 2000s, the United States provided large amounts of aid to Iraq.

The objective of this article is to provide a survey of the literature on donor motives and the quantitative impacts of such motives. The next section discusses some theoretical models on the topic. Some of the literature cited in this section also tests the empirical implications of the models. The following section provides a summary of the empirical literature. The final section provides our conclusions. 


\section{Figure 2}

\section{Total U.S. Official Development Assistance to Top Five Countries in Each Period}

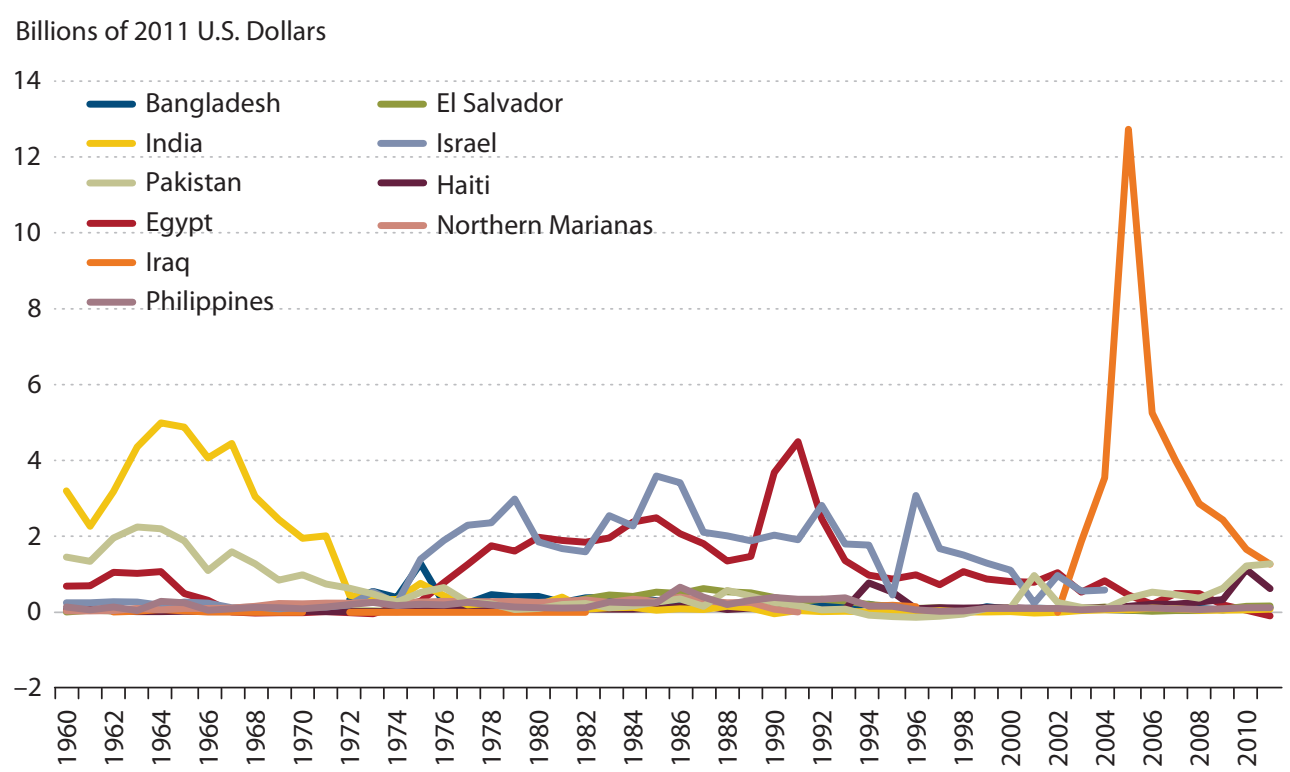

NOTES: The figure shows the official development assistance giving patterns to recipient nations that were either in the top five overall recipients and/or in the top five recipients during the Cold War era (1977-90), the interwar period (19912001), or the War on Terror (2001-11). The figure shows that, over time, the United States has had a clear preference toward providing aid to Israel and Egypt. Earlier in its history of giving official development assistance, the United States provided substantial aid to India, but that level tapered off while the United States provided substantial aid to Iraq during the War on Terror.

SOURCE: OECD.

\section{DONOR MOTIVES: THEORETICAL MODELS AND SUPPORTING EVIDENCE}

In one of the seminal papers on motives behind foreign aid, Dudley and Montmarquette (1976) identify three donor motives. First, donors expect recipient nations to express gratitude in the form of support for donors' interests, perhaps in the sphere of international politics. Second, recipients may trade more with donors, furthering the donors' economic interests. Finally, donors may care that their aid helps residents of recipient nations enjoy a better standard of living. Dudley and Montmarquette (1976) capture these ideas through the following objective function $U$ of the decisionmaker in the donor nations:

$$
U=f(X, H), \quad H=\sum_{j=1}^{m} H_{j},
$$

where $X$ is the donor nation's consumption of a private good and $H_{j}$ is the consumption of the subjectively measured impact of foreign aid to nation $j(j=1,2, \ldots m)$. Further, they assume the following functional form for $H_{j}$ : 


$$
H_{j}=\left(n_{j}\right)^{\alpha}\left(\frac{a_{j}}{y_{j}}\right)^{\gamma}, 0 \leq \alpha \leq 1, \text { and } 0 \leq \gamma<1,
$$

where $n_{j}$ is the population in the recipient nation $j, a_{j}$ is the per capita aid received by the recipient nation $j$, and $y_{j}$ is the per capita gross national product (GNP) of the recipient nation $j$. Thus, the impact perceived by the donor nation of its aid to another nation is assumed to be increasing in the following characteristics of the recipient nation: population, the per capita amount of aid received, and the per capita GNP. The donor's budget constraint is

$$
X+\sum_{j=1}^{m} n_{j} a_{j}=Y,
$$

where $Y$ is the donor nation's GNP used to (i) consume the private good $X$ and (ii) give foreign aid to the $m$ recipient nations. Using equations (1) through (3), the donor nation's constrained utility maximization problem yields the per capita aid to nation $j$ as

$$
a_{j}=\left[\frac{\gamma k}{y_{j}^{\gamma} n_{j}^{1-\alpha}}\right]^{1 /(1-\gamma)}, j 1,2, \ldots \mathrm{m},
$$

where $k$ is the marginal rate of substitution between $H$ and $X$ (reflecting the value to the donor of an additional unit of $H$ in terms of units of $X$ ). Equation (4) suggests that per capita aid to a nation $j$ rises when (i) the value to the donor of giving foreign aid $(k)$ is higher, (ii) recipient nation $j$ 's per capita income $\left(y_{j}\right)$ is lower, and (iii) the population of nation $j\left(n_{j}\right)$ is lower.

Dudley and Montmarquette (1976) extend the basic model to allow for administrative costs of aid, which rise less than proportionally to the amount of aid disbursed to a particular recipient nation. This leads to scale economies in giving per capita aid to a nation and thereby tempers the finding of equation (4), which suggests that smaller economies should receive more per capita aid. Using OECD aid commitment data from 1970, Dudley and Montmarquette find broad empirical support for their findings that lower per capita income of the aid recipients tends to raise per capita aid by the donors, while the population of the recipient nation has a more ambiguous effect.

Dudley (1979) considers the interactions between different donors in aid giving. He classifies interactions into two potential categories. First, if the foreign aid from other donor nations adds to the perceived impact of aid giving for a donor nation $j$, then he classifies such aid as an international public good. Second, if aid from other nations reduces the aforementioned impact, then such aid is classified as a national public good with interaction. He shows that the first type of aid is associated with a classic public goods problem of free-riding, where smaller nations tend to free-ride on the aid from the larger donors. The intuition is that since larger nations have a lower per capita cost for providing a certain amount of aid, they will be major providers of aid. Given positive spillovers from such aid, the net marginal benefit is lower for smaller donor nations, leading them to provide less per capita aid than larger nations. In the case of national public goods with interaction, the donor nations compete for influence through their aid. The 
result is a positively sloped reaction function for a nation with respect to aid provided by a rival nation. In equilibrium, foreign aid by each of the donor nations exceeds the level that would be obtained in the absence of such strategic competition. Empirical results of Dudley's (1979) article support the national public goods with interaction model, suggesting that the relevant group of OECD nations was engaged in some form of competition for influence.

Lahiri and Raimondos-Møller (2000) provide a political economy framework in which different ethnic groups in a donor nation provide political contributions to the donor government to lobby for aid to the respective source nations of these ethnic groups. While greater lobbying by an ethnic group leads to a greater proportion of aid to the relevant source nation, the corruptibility of the donor government, among other factors, complements such aid flows. In particular, Lahiri and Raimondos-Møller (2000) define corruption as higher when the government tends to enjoy relatively greater marginal utility from political contributions vis-à-vis national welfare. Using this definition, they show that when a richer ethnic group lobbies for a richer recipient nation, an increase in corruption decreases the proportion of aid to the poorer recipient nation. This line of analysis adds an important caveat to the studies discussed above: While the poverty of recipient nations may be an important motive in aid allocation, political economy factors such as ethnic lobbying may also influence the actual aid allocation decision.

Chong and Gradstein (2008) offer a median voter model of foreign aid, where individuals choose to contribute privately and also pay a tax on their income, which finances aid provided by their government. The aggregate aid given is the sum of private donations and official aid, where the latter is financed by income tax revenues raised for that purpose. Thus, aggregate aid is a public good for the citizens of the donor nation. Chong and Gradstein (2008) determine that the aid given is reduced by greater income inequality in the donor nation. They also show that the amount of aid given decreases with the inefficiency of the donor government in effectively providing aid to developing nations. This decrease arises from (i) a reduced willingness on the part of voters to finance inappropriate donor aid and (ii) the direct effects of inefficiencies in aid giving. The authors' empirical results are broadly consistent with their theoretical findings.

Gaytan-Fregoso and Lahiri (2000) present a model that analyzes the effect of foreign aid on illegal immigration from the perspective of a family with a migrant member. Such an analysis is useful for aid decisions because it provides information on how aid may be used for various policy goals such as containing illegal immigration. In this model, aid has two effects. First, aid narrows the gap between incomes in the host and source nations of immigrants, dissuading migration. Second, aid reduces the recipient family's marginal utility of income and hence its perceived utility cost of migration. This second effect tends to encourage migration, which leads to some ambiguity on the effects of aid on migration flows. The authors show that if the volume of initial aid is large enough, then further increases in aid must reduce immigration.

Bandyopadhyay, Sandler, and Younas (2011) evaluate the effect of aid on terrorism. They show that it may be in the interest of developed nations to provide foreign aid to developing nations to help alleviate terrorism-related threats. In their model, conditional aid is tied to the counterterrorism efforts of the aid-recipient nation. Such aid can help neutralize the capabilities of terrorist organizations at their source, leading to a global reduction in terrorism. However, such conditional aid can also lead to popular discontent in recipient nations, especially if their 


\section{Bandyopadhyay and Vermann}

people feel that their country is being paid to fight the donor nation's war. In such a situation, unconditional aid may help by improving the living conditions of the population, thereby improving the recipient government's perception among its people. The analysis identifies the factors that determine optimal allocation of aid between such conditional and unconditional uses.

Azam and Thelen (2012) present an analysis in which the number of terrorism incidents in a particular nation differs from the number produced because terrorist attacks may be imported. Thus, if enforcement funded by aid contains domestic terrorist groups, the vacuum may be filled by terrorism originating abroad, with a muted response of terrorist attacks to counterterrorism efforts of the country in question. Although the contexts of the aforementioned studies differ, they complement our understanding of how foreign aid may affect counterterrorism efforts and, in turn, the extent of terrorist threats in a particular donor or recipient nation.

\section{DONOR MOTIVES: THE EMPIRICAL LITERATURE}

Trumbull and Wall (1994) extend the Dudley and Montmarquette (1976) model by allowing donors to assign different weights to aid impact for different recipient nations. These weights are assumed to differ among recipients to capture, among other factors, the historical, strategic, and geographical differences among recipient nations as perceived by the donors. Allowing for such recipient effects in addition to period effects (i) reduces the role of the recipient's per capita income in determining per capita aid flows and (ii) amplifies the role of infant mortality (a measure of need) and civil rights in recipient nations. Simply put, a poorer nation may not necessarily receive more aid from an altruistic donor because the donor may punish the recipient government for political oppression. Along similar lines, Bandyopadhyay and Wall (2007) find that for an average recipient nation, a one-standard-deviation increase in civil/political rights and government effectiveness corresponds to increases of \$29 million and \$54 million, respectively, in total aid received by these nations.

Alesina and Dollar (2000) study donor behavior for individual nations using OECD data on bilateral aid. While they find broad support for the importance of the per capita income of recipient nations in receiving aid, they also find that ties to former colonies or strategic factors are quite significant. For example, a huge fraction of U.S. aid goes to Israel and Egypt, which are not among the poorer recipient nations. France's aid is concentrated on its former colonies, while more of Japan's aid goes to nations with comparable international political interests, as measured by similarity in U.N. voting patterns. The study also finds that donor countries reward developing countries pursuing greater democratization. Aid allocation surges to nations that liberalize in this dimension, although economic liberalization is not significantly associated with greater aid flows.

Like Alesina and Dollar (2000), more recent studies find that international political factors are important in aid giving. Kuziemko and Werker (2006) and Dreher, Strum, and Vreeland (2009) find a large positive effect of U.N. Security Council membership on aid recipients. These amounts increase in years when (i) the Security Council and/or the United Nations receive higher levels of media coverage (indicative of years with tumultuous foreign affairs) and (ii) major international events occur. Further, the levels of aid allocated to member countries of the U.N. Security 
Council "sharply increase in the year in which a country is elected to the Security Council, remain high throughout the two-year term, and return to their earlier level almost immediately upon completion of the term" (Kuziemko and Werker, 2006, p. 907). Hoeffler and Outram (2011) find that aid also increases with an increase in the correlation between the U.N. votes of a donor and recipient country, though this correlation is sensitive to specification.

Domestic politics is also quite important for aid giving. Milner and Tingley (2010) examine five types of foreign aid policy votes in the U.S. House of Representatives from 1979 to 2003. They find that votes on aid correlate with the material interests of representative constituents. Specifically, they find that voting districts with relatively higher capital endowments are more supportive of foreign aid, following the Stolper-Samuelson theorem. $\stackrel{2}{\text { Also, they find broad }}$ political support for food aid and military aid where they find no stark distributional effects between labor and capital. Political ideology also seems to play a role. For example, using data for a panel of donor countries from 1971 to 2002, Tingley (2010) finds that the more economically conservative the ideological orientation of the donor government, the less money there is in the overall aid budget.

Donors may use foreign aid to foster trade with the recipient country. If aid to a recipient nation is used by a developing nation to buy donor nation exports, it can act as an export promotion strategy for the developed nation. The potential benefits for the donor include terms-oftrade benefits and larger real incomes for factors used intensively in the export good. Following this line of reasoning, Younas (2008) finds that "a substantially larger amount of aid is provided to recipients who import capital goods, while imports by other category groups have no significant effects. Given that developed donor nations are major producers and exporters of capital goods, this result at least partially supports their trade benefits motive" (p. 661). Other authors also find that trade interest-generally measured as imports from and exports to a recipient country as a percent of donor GDP_-is correlated with higher levels of aid (Nath and Sobhee, 2007; Hoeffler and Outram, 2011; Dietrich, 2012), though these estimates may be sensitive to specification (Hoeffler and Outram, 2011).

Finkel, Pérez-Liñán, and Seligson (2007) argue there are two mechanisms through which foreign aid can promote democracy in developing nations. First, foreign aid can indirectly promote democracy "by transforming some of the structural conditions that serve as prerequisites for regime transition or survival" (p. 410). To illustrate, foreign aid "may promote modernization, encourage better economic performance, and foster class transformations, all of which may have long-term implications for democratic development" (p. 410). Second, aid can directly promote democracy "by empowering agents...that struggle for regime change in the domestic arena" (p. 410) with aid targeted toward education, political parties, labor unions, human rights groups, and women's advocacy networks. Their empirical work indicates that an increase in a donor's democracy and/or government-targeted aid increases the aid recipient's level of democracy. Bermeo (2011) confirms this result with logit regressions and Monte Carlo simulations and finds that, holding all control variables constant at their median, "a change in the amount of democratic aid from its value at the 25 th percentile to its value at the 75 th percentile is associated with an increase in the likelihood of democratic transition in a given country during a given year from a baseline of 2.15 to 3.12 percent, a 45 percent increase" (p. 2025). 


\section{Bandyopadhyay and Vermann}

Another recipient characteristic that may influence aid is the presence of conflict in the recipient nation. Balla and Reinhardt (2008) argue that "the donor's perception of the conflict [in the recipient country] will determine how useful it expects its aid to be at achieving [the donor's] interests. In light of the propensity of the conflict to alter aid's utility, the existence of the conflict may cause the donor to alter the amount, or the existence, of that aid" (p. 2568). Evidence from this article indicates that, for the 22 donors examined, 14 are more likely to allocate additional aid to countries experiencing conflict, 14 are more likely to allocate aid to a region experiencing conflict, and 9 are more likely to reduce the amount of aid allocated to a recipient as conflict increases. In an assessment of conflict and aid in a panel of 122 recipients from 1960 to 1997, Balla and Reinhardt (2008) find that proximity to conflict is statistically significant and positively correlated with respect to aid allocations. Further, they find that the likelihood for a donor to select an aid recipient increases as conflict increases in the recipient nation.

In recent years, national security has been in the forefront of foreign policy concerns. As our theoretical section outlines, it is possible to use aid to reduce threats from terrorism originating in developing nations. According to Fleck and Kilby (2010, p. 185), "starting in the mid 1990s and continuing into the War on Terror, the importance of need as a criterion for aid eligibility fell so that the probability that a higher income (less poor) developing country would receive aid increased over time." $\underline{3}$ They find that higher-income recipients were 9 percent more likely to receive aid during the War on Terror than during the Cold War era. Demierl-Pegg and Moskowitz (2009) confirm this result: They find that economic development (per capita GDP) had a larger impact on the probability of receiving foreign aid during the Cold War than strategic interests (bilateral trade and political alliance) and that per capita GDP also outweighed bilateral trade and regime type in aid allocation. Further, the impact of economic development and human rights on the probability of a country receiving aid and the amount of aid to that country were higher during the 1990s than during the Cold War era. Indeed, aid budgets overall increased among 22 donor countries since the start of the War on Terror (Dreher and Fuchs, 2011), and aid allocation decisions changed during this period after controlling for natural disasters, recipient country size, recipient country movement to democracy, and U.N. votes. Young and Findley (2011) find that targeted (conditional) aid can be an effective tool to deter terrorism, especially when directed at education, health, civil society, and conflict prevention in the recipient country.

\section{CONCLUSION}

As many poorer nations started on their path of development in the postcolonial period, former colonial powers tried to facilitate this process through provision of resources in the form of foreign aid. This motive was central in foreign aid flows throughout the 1960s and still remains one of the multiple objectives that determine aid. In addition to pure altruism, strategic interests have always been relevant. In the Cold War era, aid was used as an instrument to buy allegiance. More recently, aid has focused substantially on security concerns, marked especially by the watershed event of September 2001. This review has attempted to provide a summary of some important theoretical models and empirical findings proposed in the literature to further critical thinking about these issues. 


\section{NOTES}

1 We take our definition of foreign aid from Perkins, Radelet, and Lindauer (2006, p. 521):"Foreign aid consists of financial flows, technical assistance, and commodities given by the residents of one country to the residents of another country, either as grants or as subsidized loans." Precise characterization of what is and what is not foreign aid is more nuanced.

$\underline{2}$ If aid fosters domestic production of a certain good (either directly through production of some U.S. good that may be given as aid or indirectly through demand for a U.S. good from aid-receiving nations), then Stolper-Samuleson effects will predict that the real income of factors intensive in these goods will rise. Given that the United States is relatively capital abundant compared with most of the poorer, labor-abundant developing nations, StolperSamuelson effects would suggest that U.S. exports will raise the real income of capital.

$\underline{3}$ This analysis excluded countries such as Egypt, Israel, Iraq, and Afghanistan from analysis. These countries exhibit high levels of strategic importance but were excluded because of either a lack of data (Iraq and Afghanistan) or because they were extreme outliers (Egypt and Israel).

\section{REFERENCES}

Alesina, Alberto and Dollar, David. "Who Gives Foreign Aid to Whom and Why?" Journal of Economic Growth, March 2000, 5(1), pp. 33-63.

Azam, Jean-Paul and Thelen, Véronique. "Where to Spend Foreign Aid to Counter Terrorism." Working Paper No. 725, Institut d'Économie Industrielle, June 2012; http://idei.fr/doc/wp/2012/wp idei 725.pdf.

Balla, Eliana and Reinhardt, Gina Yannitell. "Giving and Receiving Foreign Aid: Does Conflict Count?" World Development, December 2008, 36(12), pp. 2566-85.

Bandyopadhyay, Subhayu; Sandler, Todd and Younas, Javed. "Foreign Aid as Counterterrorism Policy." Oxford Economic Papers, July 2011, 63(3), pp. 423-47.

Bandyopadhyay, Subhayu and Wall, Howard J. "The Determinants of Aid in the Post-Cold War Era." Federal Reserve Bank of St. Louis Review, November/December 2007, 89(6), pp. 533-47; http://research.stlouisfed.org/publications/review/07/11/Bandyopadhyay.pdf.

Bermeo, Sarah B. "Foreign Aid and Regime Change: A Role for Donor Intent." World Development, November 2011, 39(11), pp. 2012-31.

Chong, Alberto and Gradstein, Mark. "What Determines Foreign Aid? The Donors' Perspectives." Journal of Development Economics, August 2008, 87(1), pp. 1-13.

Demirel-Pegg, Tijen and Moskowitz, James. “U.S. Aid Allocation: The Nexus of Human Rights, Democracy, and Development." Journal of Peace Research, March 2009, 46(2), pp. 181-98.

Dietrich, Simone. "Bypass or Engage? Explaining Donor Delivery Tactics in Foreign Aid Allocation." International Studies Quarterly, 2012; early view, doi: 10.1111/isqu.12041.

Dreher, Axel and Fuchs, Andreas. “Does Terror Increase Aid?" Public Choice, December 2011, 149(3-4), pp. 337-63.

Dreher, Axel; Sturm, Jan-Egbert and Vreeland, James Raymond. “Development Aid and International Politics: Does Membership on the UN Security Council Influence World Bank Decisions?" Journal of Development Economics, January 2009, 88(1), pp. 1-18.

Dudley, Leonard M. "Foreign Aid and the Theory of Alliances." Review of Economics and Statistics, November 1979, 61(4), pp. 564-71.

Dudley, Leonard M. and Montmarquette, Claude. "A Model of the Supply of Bilateral Foreign Aid." American Economic Review, March 1976, 66(1), pp. 132-42.

Finkel, Steven E.; Pérez-Liñán, Aníbal S. and Seligson, Mitchell A. “The Effects of U.S. Foreign Assistance on Democracy Building, 1990-2003." World Politics, April 2007, 59(3), pp. 404-39. 


\section{Bandyopadhyay and Vermann}

Fleck, Robert K. and Kilby, Christopher. "Changing Aid Regimes? U.S. Foreign Aid from the Cold War to the War on Terror." Journal of Development Economics, March 2010, 91(2), pp. 185-97.

Gaytan-Fregoso, Helena and Lahiri, Sajal. "Foreign Aid and Illegal Immigration." Journal of Development Economics, December 2000, 63(2), pp. 515-27.

Hoeffler, Anke and Outram, Verity. "Need, Merit or Self-Interest—What Determines the Allocation of Aid?" Review of Development Economics, May 2011, 15(2), pp. 237-50.

Kuziemko, llyana and Werker, Eric D. “How Much Is a Seat on the Security Council Worth? Foreign Aid and Bribery at the United Nations." Journal of Political Economy, October 2006, 114(5), pp. 905-30.

Lahiri, Sajal and Raimondos-Møller, Pascalis. "Lobbying by Ethnic Groups and Aid Allocation." Economic Journal, March 2000, 110(462), pp. C62-79.

Milner, Helen V. and Tingley, Dustin H. "The Political Economy of U.S. Foreign Aid: American Legislators and the Domestic Politics of Aid." Economics and Politics, July 2010, 22(2), pp. 200-32.

Nath, Shyam and Sobhee, Sanjeev K. "Aid Motivation and Donor Behavior." American Review of Political Economy, 2007, 5(1), pp. 1-13.

Perkins, Dwight H.; Radelet, Steven and Lindauer, David L. Economics of Development. Sixth Edition. New York: W.W. Norton, 2006.

Tingley, Dustin H. "Donors and Domestic Politics: Political Influences on Foreign Aid Effort." Quarterly Review of Economics and Finance, February 2010, 50(1), pp. 40-49.

Trumbull, William N. and Wall, Howard J. "Estimating Aid-Allocation Criteria with Panel Data." Economic Journal, July 1994, 104(425), pp. 876-82.

United States Agency for International Development (a). “USAID History.” Undated; http://www.usaid.gov/who-we-are/usaid-history.

United States Agency for International Development (b). "What We Do." Undated; http://www.usaid.gov/what-we-do.

Younas, Javed. "Motivation for Bilateral Aid Allocation: Altruism or Trade Benefits." European Journal of Political Economy, September 2008, 24(3), pp. 661-74.

Young, Joseph K. and Findley, Michael G. "Can Peace Be Purchased? A Sectoral-Level Analysis of Aid's Influence on Transnational Terrorism." Public Choice, December 2011, 149(3-4), pp. 365-81. 